\title{
Which factors most influence heartwood distribution and radial growth in plantation teak?
}

\author{
Adzo Dzifa KoKUTSE ${ }^{1 *}$, Alexia StoKes², Nomessi Kuma KoKUTSE ${ }^{3}$, Kouami KoKou' ${ }^{1}$ \\ ${ }^{1}$ Laboratoire de Botanique et Ecologie Végétale, Faculté des Sciences, Université de Lomé, BP1515, Lomé, Togo \\ ${ }^{2}$ INRA, AMAP, 34398 Montpellier Cedex 5, France \\ ${ }^{3}$ CIRAD, AMAP, 34398 Montpellier Cedex 5, France
}

(Received 4 March 2009; accepted 18 August 2009)

Keywords:

dendroecology /

precipitation /

Tectona grandis L.f /

temperature /

social status /

Togo

\begin{abstract}
- To investigate the effect of climate on radial growth in young plantation grown teak (Tectona grandis L.), growth ring width was measured in 105 trees and correlated to precipitation and temperature data.

- The social status of trees within the stand was also determined and cross-sectional area (CSA) for the trunk correlated to the proportion of heartwood (HW) within the tree. HW develops asymmetrically in leaning stems of some conifer species, but it is not known if this phenomenon also occurs in broadleaf species. Therefore, we measured HW proportion in leaning and straight stems, along with the number of growth rings in the HW.

- Annual ring width depended strongly on mean monthly temperature during the rainy season and the most significant relationships were found corresponding to the months of June and July. With regard to the weaker relationship between precipitation and radial growth, correlations were highest during the period of bud-break at the beginning of the rainy season.

- The very high stand density affected radial growth, particularly in suppressed trees, which responded little to thinning operations. HW formation was greatest in dominant trees, and was highly regressed with stem CSA.

- Therefore, rapid growth of young stands should be encouraged by reducing stand density. Asymmetric HW formation occurred in both leaning and straight trees, and was significantly greater along the upper sides of leaning stems. It is probable that this eccentric HW formation is linked to mechanical loading on the tree.
\end{abstract}

Résumé - Quels facteurs influencent le plus la distribution du bois de cœur et la croissance radiale dans les plantations de teck ?

- Afin d'analyser l'effet du climat sur la croissance radiale des arbres dans les plantations de teck, la largeur de cernes a été mesurée sur 105 arbres. Les données pluviométriques et de température ont été corrélées aux largeurs de cernes mesurées.

- Le statut social des arbres à l'intérieur du peuplement a été déterminé et l'aire de la section transversale des troncs a été mise en relation avec la proportion du bois de cœur (HW) formé. Le bois de cœur peut se développer de manière asymétrique chez les espèces de conifères, mais la formation de bois de cœur excentré n'est pas signalée chez les espèces feuillues. Ainsi la proportion de HW dans le tronc a été mesurée chez les arbres droits et penchés, ainsi que le nombre de cernes de l'aubier (SW) transformé en HW.

- Les résultats ont montré que la largeur des cernes dépend fortement des températures durant la saison pluvieuse. Les meilleures corrélations entre la croissance radiale et la température sont celles des mois de juin et de juillet. La largeur des cernes est plus faiblement dépendante de la pluviométrie et les corrélations obtenues sont élevées aux périodes d'ouverture des bourgeons, au début de la saison des pluies.

- La forte densité du peuplement affecte la croissance radiale, particulièrement chez les individus dominés, qui réagissent très peu aux opérations d'éclaircies. La proportion du HW est plus importante chez les arbres dominants et est fortement corrélée au diamètre du tronc.

- Par conséquent la croissance rapide des jeunes peuplements devrait être encouragée en réduisant leur densité. La formation du HW excentré se produit aussi bien chez les arbres droits que penchés. La proportion de HW est significativement plus importante du côté supérieur des troncs penchés, sans doute en raison du chargement mécanique sur l'arbre.

\footnotetext{
* Corresponding author: kokutse@ cirad.fr
} 


\section{INTRODUCTION}

Over 11000 ha of teak (Tectona grandis L.f.) plantations currently exist in Togo (FAO, 2001). Planted at the beginning of the 20th century, this exotic species is well adapted to the climate of West Africa. Nevertheless, the plantations are poorly maintained or even abandoned and often destroyed by fires (Behaghel, 1999). Stand density is high (10002000 stems ha $^{-1}$ ) and rotation times can be up to $70 \mathrm{y}$, even though shorter rotation times would be more economically viable for a similar wood quantity and quality (Kokutse et al., 2004). The poor management of the plantations thus leads to a very heterogeneous population within the stand, with a small number of dominant or co-dominant individuals and a larger number of suppressed trees. Radial growth depending on the social status of individuals has been examined in temperate timber species (Bert and Danjon, 2006; Eckstein et al., 1989) but little information exists concerning tropical species (Morataya et al., 1999; Sahri et al., 1998; Wadsworth et al., 2003). If the influence of social status on radial growth and wood quality in teak was better understood, it would be possible to manipulate such characteristics, taking into account the social status of trees within a plantation (Morataya et al., 1999; Sahri et al., 1998).

Teak wood is highly durable and mechanically resistant to loading, and is therefore much in demand for house and boat construction purposes, outdoor furniture and flooring. This natural durability is largely due to the chemical composition of the non-functional heartwood (HW), found at the centre of the tree (Bhat and Florence, 2003; Haupt et al., 2003; Kokutse et al., 2006). Therefore, an increase in HW volume through forest management practices would be very valuable, particularly in Togo, which is a low natural forest cover country, and where teak plantations are an important timber source. It has been found that HW volume is positively correlated with stem diameter at breast height (DBH), annual ring width and teak tree height (Bhat, 1995, Kjaër et al., 1999) as well as growth rate (Kokutse, 2002). However, no clear relationship could be established with thinning operations in juvenile plantation teak from Costa Rica (Pérez and Kanninen, 2005). In some temperate conifer species, HW formation is greater in leaning stems or branches, with extra HW formed on the side of the stem held in compression, although it is not yet clear what the mechanism is which triggers this eccentric shape (Berthier et al., 2001; Stokes and Berthier, 2000), nor if the same phenomenon exists in broadleaf species. In the temperate species Maritime pine (Pinus pinaster Ait.), no differences in relative HW volume occurred within a plantation, even when social status was taken into account (Bert and Danjon, 2006). However, in Norway spruce (Picea abies L.) social status was found to influence sapwood width, with dominant trees having a thicker sapwood (Sellin, 1996) and lower stem taper (Longuetaud et al., 2006). To our knowledge, no such studies have been carried out on tropical tree species. Therefore, the relationship between HW formation in straight and leaning stems, radial growth and size status of plantation teak trees would provide very useful information for forest managers throughout West Africa.
The use of dendrochronology to study growth ring width in trees has shown that it is possible to successfully date many tropical species in West Africa, and the occurrence of annual rings has been demonstrated in teak in Thailand (Pumijumnong et al., 1995), India (Priya and Bhat, 1998; Shah et al., 2007) and Central America (Devall and Parresol, 2005). Radial growth depends on a combination of climate and local environmental factors including e.g. soil type, light availability and competition from neighbours. Annual ring width across a wide range of tree species has been found to be correlated with climatic data from several specific months in either the preceding or the current year's growth of a tree (Brienen and Zuidema, 2005; Devall and Parresol, 2005; Fritts 1976; Trouet et al., 2006). Teak radial growth has also been found to be correlated with monthly precipitation in East Java (Murphy, 1994), India (Shah et al., 2007) and Thailand (Pumijumnong et al., 1995) as well as monthly temperature in Puerto Rico (Devall and Parresol, 2005). Although studies have been carried out in temperate species on the interaction between climate response and social status on radial growth (e.g. Piutti and Cescatti, 1997), in large-leaved trees such as teak, to our knowledge, no information exists. Dominant teaks possess crowns high in the canopy and thus may be susceptible to high temperatures resulting in increased evapotranspiration, which would in turn be reflected in radial growth.

Other factors affecting radial growth are silvicultural operations e.g. thinning, which usually results in a release of radial growth in the remaining trees (Plauborg, 2004). It is not known whether the size status of the individual within the plantation influences the percentage increase in radial growth after thinning. Therefore, we aim at establishing whether climate and thinning affect annual radial growth in teak, taking into account tree size status within a plantation. The size status of an individual within a plantation may also influence physiological processes e.g. juvenility and ageing, because teak has a longer period of juvenile wood (JW) formation in certain locations where trees grow fast (Bhat et al., 2001). JW is formed from a juvenile cambium during the early years of physiological activity (Bhat et al., 2001; Medzegue et al., 2007; Zobel and van Buijtenen, 1989). Adult wood (AW) is then produced and usually has thinner annual growth rings, a higher longitudinal modulus of elasticity $\left(E_{L}\right)$, higher density and greater dimensional stability due to changes in xylem structure. The age at which AW begins to form depends largely on species, but in teak, was found to develop at the ages of 15 to $25 \mathrm{y}$, depending on the wood property measured, growth rate, and individual tree and plantation site (Bhat et al., 2001). As the influence of tree social status on JW formation in teak is not known, we aimed at investigating the relationship, if any, in plantation trees.

The aim of this study therefore, was to determine which factors most influence HW distribution and radial growth in young plantation teak. HW distribution was examined with regard to tree social status and stem lean. The influence of social status on radial growth and interactions with the climate variables, mean monthly temperature and precipitation was also investigated along with the effect of social status on 


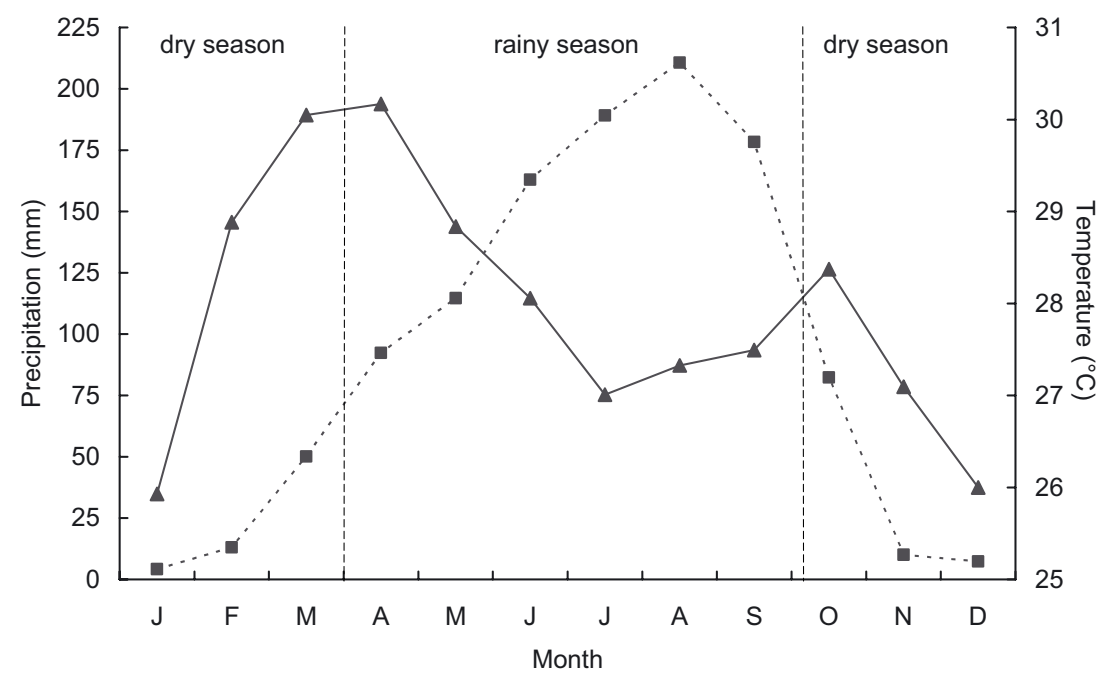

Figure 1. At the study site, the rainy season lasts from April to October (mean monthly precipitation: black squares, dotted line. The rest of the year is dry, (mean monthly temperature: black triangles, solid line).

Table I. Shoot characteristics and number of trees $(n)$ in each ecological class. Data are means \pm standard error. Where letters in superscript differ, data are significantly different.

\begin{tabular}{lccccc}
\hline Stem characteristic & Social status & \\
& \cline { 2 - 3 } & Suppressed & Co-dominant & Dominant & $F$ \\
\hline Dbase (m) & $0.27 \pm 0.03^{\mathrm{a}}$ & $0.36 \pm 0.02^{\mathrm{b}}$ & $0.38 \pm 0.02^{\mathrm{c}}$ & 56.13 & $<0.001$ \\
DBH (m) & $0.21 \pm 0.02^{\mathrm{a}}$ & $0.26 \pm 0.08^{\mathrm{b}}$ & $0.30 \pm 0.01^{\mathrm{c}}$ & 96.33 & $<0.001$ \\
Height to first live branch (m) & $9.9 \pm 1.5^{\mathrm{a}}$ & $12.2 \pm 2.6^{\mathrm{b}}$ & $16.0 \pm 1.3^{\mathrm{c}}$ & 16.31 & $<0.001$ \\
Tree height (m) & $16.3 \pm 1.7^{\mathrm{a}}$ & $19.7 \pm 1.6^{\mathrm{b}}$ & $22.8 \pm 1.5^{\mathrm{c}}$ & 25.55 & $<0.001$ \\
Stem Taper & $0.8 \pm 0.1$ & $0.8 \pm 0.1$ & $0.7 \pm 0.1$ & 4.83 & $\mathrm{~ns}$ \\
Mean sapwood width at BH (mm) & $20.1 \pm 4.8$ & $24.1 \pm 5.9$ & $21.0 \pm 4.8$ & 2.36 & $\mathrm{~ns}$ \\
Mean sapwood area at BH (mm $\left.{ }^{2}\right)$ & $126.7 \pm 4.7^{\mathrm{a}}$ & $183.3 \pm 13.1^{\mathrm{b}}$ & $156.8 \pm 9.8^{\mathrm{b}}$ & 10.46 & $<0.001$ \\
Proportion of HW at BH & $0.94 \pm 0.01^{\mathrm{a}}$ & $0.99 \pm 0.06^{\mathrm{b}}$ & $1.07 \pm 0.02^{\mathrm{c}}$ & 18.15 & $<0.001$ \\
$n$ & 82 & 12 & 11 & 2.105 & \\
\hline
\end{tabular}

ns is not significant. DBH: The diameter at breast height; Dbase: the diameter at tree base; BH: breast height; HW: heartwood.

JW formation. Results are discussed with regard to implications for forest management in Togo.

\section{MATERIALS AND METHODS}

\subsection{Site description}

The study site was situated at Tchorogo $\left(1^{\circ} 00^{\prime} \mathrm{E}, 8^{\circ} 21^{\prime} \mathrm{N}\right)$ in central Togo, West Africa. This area of Togo is covered by Guinean woody savannas and is situated at an altitude of $200-400 \mathrm{~m}$ (Aubréville, 1937; Ern, 1979). At Tchorogo, two major seasons exist in a year, one long rainy season lasting 6-8 months, followed by a long dry season (Fig. 1). Mean annual precipitation is 1300 $1600 \mathrm{~mm}$ and temperatures vary from $24-30{ }^{\circ} \mathrm{C}$ (Kokou, 1998, Fig. 1), with extreme temperatures reaching $40{ }^{\circ} \mathrm{C}$. Soil type is ferruginous soil with a clay/sandy silt structure (Kokutse et al., 2004).

Tchorogo has been planted with many teak plantations in recent years. The 6 ha site chosen for this study was planted in 1980, and thinned in 1986, 1995 and 2004. In 2004, stem density was $1200 \mathrm{ha}^{-1}$ when 105 trees were randomly selected from within the stand. Dominant trees are those which are taller than the canopy; co-dominant trees have crowns situated within the canopy and suppressed trees are the smallest with the lowest incident light on the crown and are found beneath the canopy. We classed trees into three groups depending on tree height: dominant $(\geq 21.30 \mathrm{~m})$, co-dominant (18.01-21.29 m) and suppressed $(\leq 18.00 \mathrm{~m})$ trees (Tab. I).

Total stem length and length to the first living branch were measured and stem taper calculated as tree height/DBH (Tab. I). Some trees were noticed to be leaning but the majority had straight stems. Although the angle of lean was not measured, it was noted whether the tree was inclined or straight, and also where each stem disc was located with regard to the direction of lean, as stem lean may influence HW formation (Berthier et al., 2001).

\subsection{Measurements of growth rings}

One disc was removed from each tree $(n=105)$ at the stem base, but above any fluting due to root formation (at a height of 
approximately $0.15-0.20 \mathrm{~m}$ ). We chose to measure ring width at the stem base so as to have the maximum number of growth rings possible. Each disc from the stem base was then polished using a handheld sander and then by hand using fine grain sandpaper until the growth rings were clearly visible. The surface of each disc at the stem base was scanned and growth ring number and width (to a precision of $0.001 \mathrm{~mm}$ ) measured using Windendro (Régent Instruments Inc., Quebec City, Canada). Initially, it was necessary to visually determine a skeleton plot (Stokes and Smiley, 1968). Each successive measurement was then visually cross-dated with the skeleton plot. Although this procedure was lengthy, it was required to verify that any ring anomalies were taken into consideration. For each disc, the growth rings were individually followed around the disc, especially in discs with irregular boundaries. The width of each growth ring was measured in four directions around the stem, unless ring formation was very irregular, in which case, measurements were taken at eight points. Therefore, data for each individual ring width was a mean from four or eight measurements. Where necessary, manual measurements were made to adjust the automatic measured procedure carried out by Windendro. Nevertheless, it was relatively easy to measure ring width in these samples, as the boundary between rainy and dry seasons was quite sharp. Wedging within rings was not extreme, but in highly eccentric cross-sections, growth ring width was variable around the stem.

Measurement of heartwood proportion and eccentricity.

Using methodology described elsewhere (Berthier et al., 2001; Kokutse et al., 2004; Pardé and Bouchon, 1988), we measured the distance from the stem pith to the heartwood-sapwood boundary ( $\mathrm{r} 1$, r2, r3, r4) and inner bark (R1, R2, R3, R4) in four directions around the trunk in discs taken from BH. Sapwood (SW) width and area was calculated as the difference between the two after using equations (1) and (2). If the heartwood-sapwood boundary was irregular, we carried out up to eight measurements around the disc. The crosssectional area (CSA) was calculated using equations (1) and (2). The proportion of HW per disc was then calculated.

$$
\begin{array}{r}
S_{t}=\frac{\pi\left(\sum_{i=1}^{4} R_{i}^{2}\right)}{4} \\
S_{H W}=\frac{\pi\left(\sum_{i=1}^{4} r_{i}^{2}\right)}{4}
\end{array}
$$

where: $S_{t}$ is the CSA of the disc and $\mathrm{S}_{H W}$ is the CSA of heartwood.

\subsection{Statistical analysis}

The program SegReg (Oosterbaan, 2005) was used to carry out segmented linear regression analysis on mean ring width with cambial age, to estimate the age limit between the formation of JW and AW (Alteyrac et al., 2006; Bhat et al., 2001; Medzegue et al., 2007) in each size class of trees. Although several wood anatomical and physical properties are necessary to determine correctly the breakpoint between JW and AW, we can nevertheless obtain useful information concerning the influence of status on one predictor of AW and AW formation. The model consists of finding two linear regressions to characterize ring width as a function of cambial age. The threshold or breakpoint between JW and AW can be considered as the transition age between the two and is considered as equation (3) for JW and equation (4) for AW:

$$
\begin{array}{lll}
Y=a X+b+\varepsilon & \text { for } & X \leqslant X_{0} \\
Y=c X+d+\varepsilon & \text { for } & X>X_{0}
\end{array}
$$

where $Y$ is ring width and $a, b, c$ and $d$ are the parameters and $X$ is cambial age. $X_{0}$ is unknown and determined with an iterative method $(n=7)$ to estimate the best statistical coefficient of explanation of the model including the two regressions by a numerical optimization method (Alteyrac et al., 2006; Oosterbaan, 2005). Although other authors have used different models to estimate the limit between JW and AW, segmented linear regression analysis appears to be the most useful (Alteyrac et al., 2006; Bhat et al., 2001), especially on specimens with a low number of annual growth rings, as is the case in our study.

To remove the influence of biological growth trends on ring width, data were standardized using the first difference of the inverse hypersine (Van Deusen, 1990). We used the program DENDROCLIM2002 to determine if mean annual ring width was a function of monthly precipitation or temperature for the current or preceding years (Biondi and Waikul, 2004). DENDROCLIM2002 uses bootstrapped confidence intervals to estimate the significance of both correlation and response function coefficients, the benefits and disadvantages of which are discussed in Biondi and Waikul (2004). DENDROCLIM2002 uses 1000 bootstrapped samples to compute response and correlation coefficients, and to test their significance at the 0.05 level. Bootstrap samples are drawn at random with replacement from the calibration interval. Median correlation and response coefficients are deemed significant if they exceed, in absolute value, half the difference between the 97.5th quartile and the 2.5th quantile of the 1000 estimates (Biondi and Waikul, 2004). The same analysis was also carried out for trees within each social class only. It should therefore be possible to determine whether radial growth of dominant and suppressed trees was similarly affected by climate conditions or not.

HW proportional data were arcsine square root transformed prior to analysis. For non-proportional data (tree characteristics), the normality of distribution was tested using an Anderson-Darling test. If data were not normally distributed $(P<0.05)$, a logarithmic transformation was performed. Analysis of covariance was used to investigate the linear relationships in tree height with height to live crown depending on tree social status and using DBH as a covariate. Analysis of variance (general linear model-GLM) and post-hoc Fisher least significant difference (LSD) tests were used to determine differences in mean tree height, height to first live branch, stem taper, mean SW width, mean SW area at $\mathrm{BH}$ and proportion of $\mathrm{HW}$ at $\mathrm{BH}$, depending on tree status in the plantation (dominant, co-dominant or suppressed), using stem disc CSA at $\mathrm{BH}$ as a covariate. Differences in HW proportion and the number of rings in the HW from different regions around the stem were also tested in the same way. All mean data presented are \pm standard error.

\section{RESULTS}

\subsection{Effect of social status on growth characteristics}

Dominant trees were significantly taller with thicker stems than either co-dominant or suppressed trees, but no differences were found in stem taper between classes (Tab. I). The height to the live crown was significantly regressed with total tree 


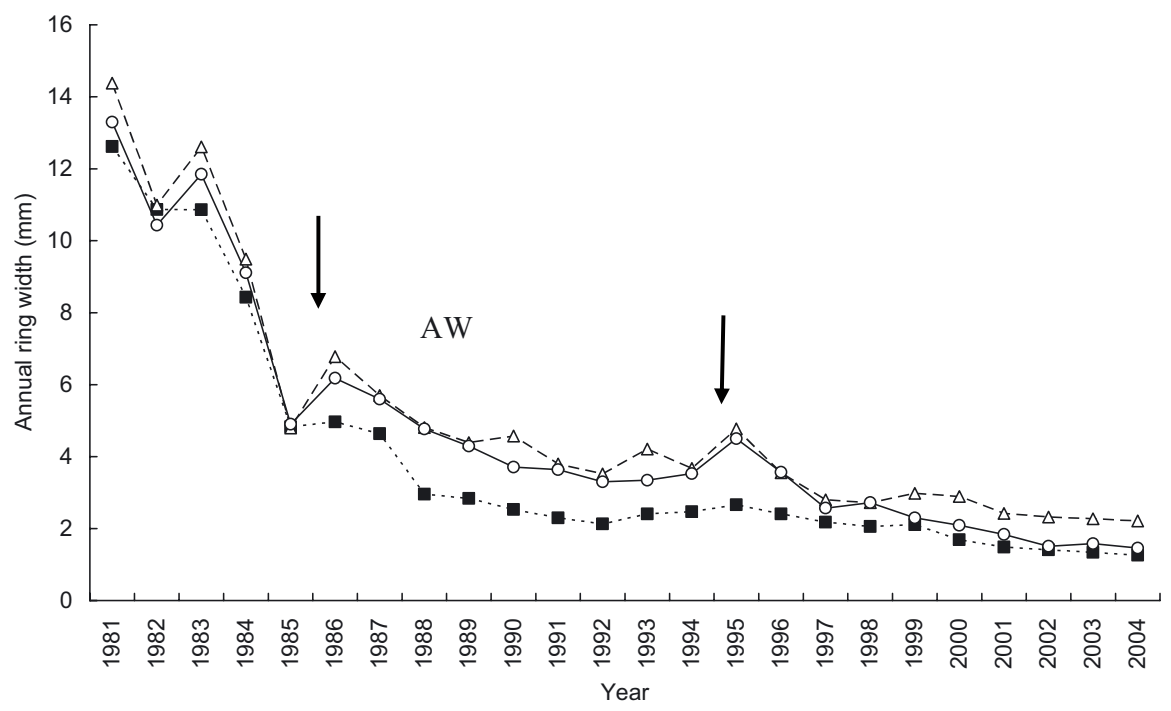

Figure 2. Mean annual ring width in dominant trees (black triangles, dashed line) had larger ring widths than co-dominant (white circles, solid line) and suppressed trees (black squares, dotted line). Black arrows indicate that thinnings were carried out in 1986 and 1995 . AW indicates that adult wood starts forming at 8-9 y old.

height $\left(y=1.39 x-0.71, R^{2}=0.57, P<0.001\right)$ and was $61 \%$ of total tree height in suppressed trees, $62 \%$ in co-dominant and $70 \%$ in dominant trees (Tab. I).

\subsection{Analysis of growth ring data}

The growth boundary marking the transition between the rainy and the dry season was easy to distinguish, and only one growth ring was formed per year. No missing or false growth rings were observed. When all trees were considered together, mean annual ring width decreased strongly from $13 \mathrm{~mm}$ in 1981 to $1.6 \mathrm{~mm}$ in 2004. In the second year of growth, a sharp decrease in ring width was noted, but in the third year, ring width increased strongly. In general, ring width decreased up to the cambial age of 8-9 y, after which, decrease was very slight with age (Fig. 2). Thinnings carried out in 1986 and 1995 resulted in a release of radial growth, but which then progressively diminished with age (Fig. 2). In dominant and co-dominant trees, the first thinning resulted in an increase in radial growth of $30 \%$, but after the second thinnings, the increase was only $20 \%$. However, in suppressed trees, any augmentation in radial growth after the first thinning was negligible (3\%) and after the second thinning was only $7 \%$ (Fig. 2).

Segmented regression analysis showed that when all trees were pooled together, a breakpoint was formed at the age of 8.6 y $\left(y=-1.23 x+13.86, R^{2}=0.88, P<0.001\right)$ with ring width changing little after this age $(y=-0.15 x+5.19$, $\left.R^{2}=0.80, P<0.001\right)$. The position of the breakpoint did not differ significantly depending on tree size class (Fig. 2). In suppressed and dominant trees, the age at which ring width stopped decreasing significantly was $8.4 \mathrm{y}$. After this point, a plateau was reached and little variation was noted. In codominant trees, the breakpoint was $9.5 \mathrm{y}$.
Significant correlations were observed between annual ring width and both monthly precipitation and temperature of the preceding and current years of growth. When all trees were considered together, teak annual ring width was significantly and positively correlated with the current year's precipitation for the months of March and May, and the month of March for the preceding year (Fig. 3). Negative correlations were found with the months of February and October in the current year (Fig. 3). No significant results were found after the response function analysis. When the same analysis was carried out with regard to temperature, ring width was positively correlated with mean monthly temperature for February and AprilOctober in the preceding year and for February, April-August, and October for the current year (Fig. 3). These months corresponded largely to the rainy season (Fig. 1). Mean monthly temperature was negatively correlated with ring width for the month of January of the current year only (Fig. 3). Response function analysis was significant for the months of July in the preceding year and June and July in the current year (Fig. 3). When correlations and response function analysis were carried out between monthly climate data and annual ring width for each social class of trees, each group of trees behaved in the same way, with the same significant correlations as found for all trees together. Therefore, no differences were found indicating that dominant trees behaved differently to co-dominant and suppressed trees during months of high temperatures and precipitation.

\subsection{Measurement of heartwood proportion and eccentricity}

When all trees were considered together, log CSA for HW was positively regressed with $\log$ CSA for the trunk at a height of $1.3 \mathrm{~m}$ above ground level $\left(y=1.11 x-0.47, R^{2}=0.95\right.$, 


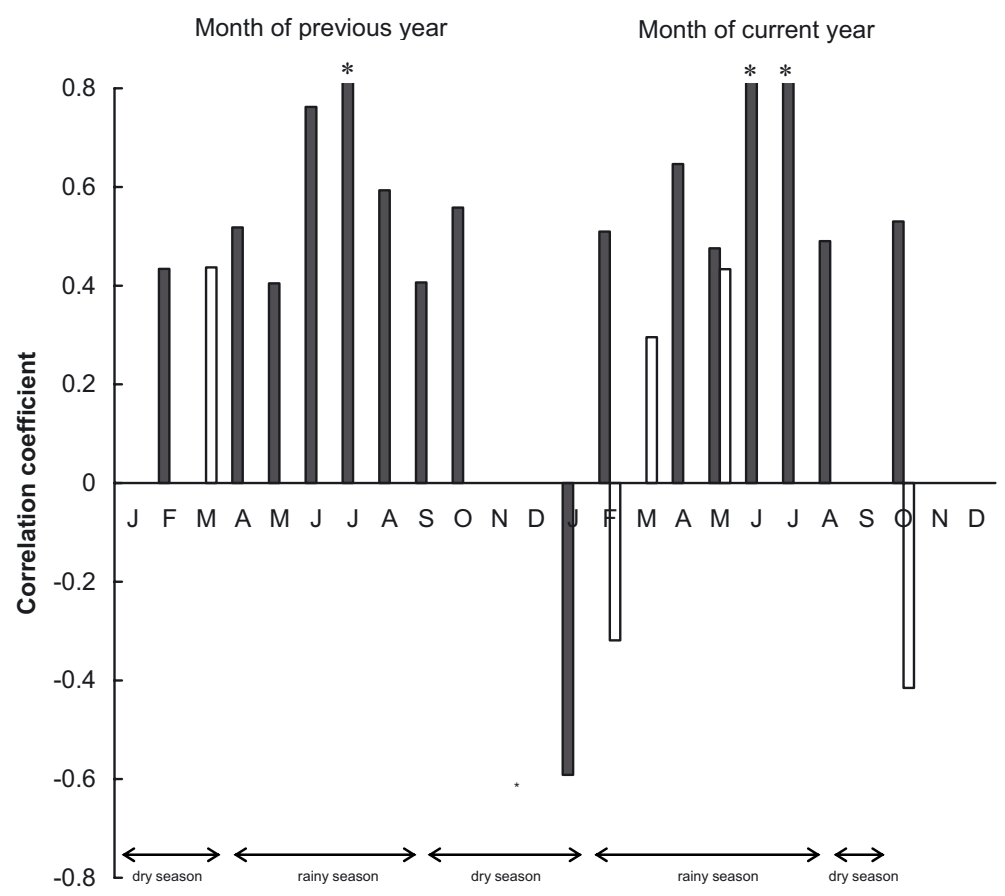

Figure 3. Significant correlation coefficients between annual ring width and monthly precipitation (white bars) and temperature data (black bars) for the previous and current years of growth, for all trees regardless of social class. Relationships which were significant between ring width and monthly climate data after response function analysis are indicated with an asterisk.

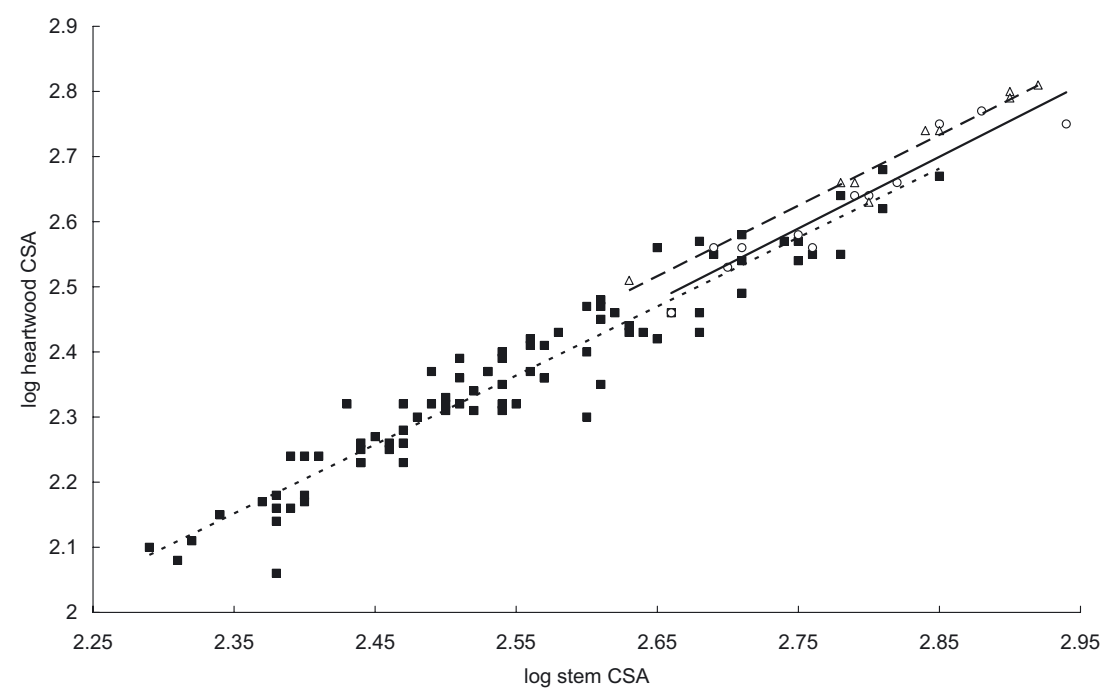

Figure 4. Dominant trees (white triangles, dashed line: $y=1.06 x-0.34, R^{2}=0.92, P<0.001$ ) produced significantly more heartwood (HW) per unit area of trunk, compared to co-dominant (white circles, solid line: $y=1.1 x-0.44, R^{2}=0.90, P<0.001$ ) and suppressed trees (black squares, dotted line: $\left.y=1.09 x-0.36, R^{2}=0.96, P<0.001\right)$. CSA: cross-sectional area.

$P<0.001)$. When trees were considered separately, depending on their social status, dominant trees produced significantly more HW, compared to co-dominant and suppressed trees $\left(F_{2,100}=4.87, P=0.01\right.$, Fig. 4$)$.

The proportion of $\mathrm{HW}$ at $\mathrm{BH}$ varied from $49-81 \%$ in all trees. The proportion of HW was 77, 70 and $65 \%$ in dominant, codominant and suppressed trees, respectively. The mean proportion of HW was significantly greater in dominant trees compared to both other social classes, however, mean SW width did not differ significantly between classes (Tab. I). Although mean SW CSA was significantly lower in suppressed trees, no differences were found between co-dominant and dominant trees (Tab. I).

HW formation at $\mathrm{BH}$ was irregular in both straight and leaning trees but not to the same extent. In straight trees, the distance from the stem pith to the HW-SW boundary differed 


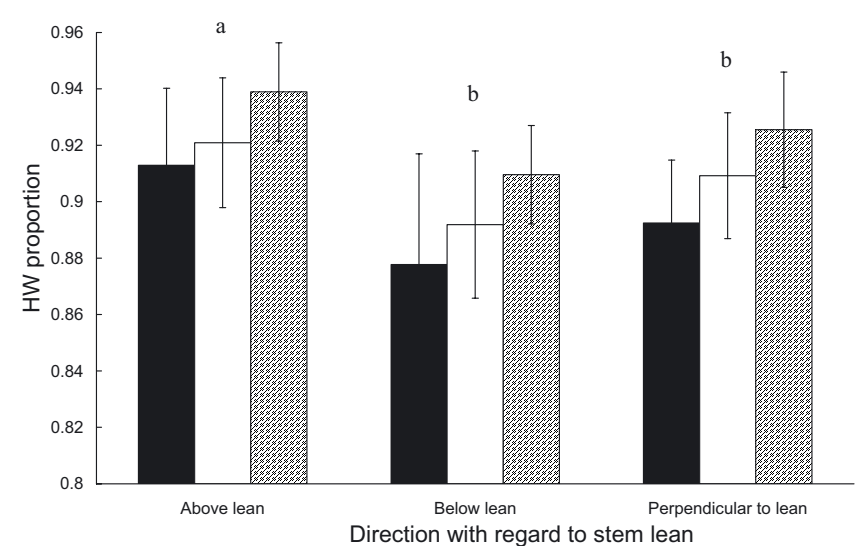

Figure 5. When all leaning trees were considered together, regardless of social status, the mean proportion of heartwood (HW) was significantly greater on the side of the tree above the direction of lean, compared to both perpendicular and below the direction of lean. No significant differences were found in HW proportion between suppressed trees (black bars), co-dominant trees (white bars) and dominant trees (hatched bars). Where letters in superscript differ, mean data are significantly different with regard to the direction of stem lean.

significantly around the stem $\left(F_{3,350}=54.5, P<0.001\right)$ and the number of annual rings transformed into $\mathrm{HW}$ also differed significantly around the stem $\left(F_{3,354}=19.8, P<0.001\right)$, although no preferential direction occurred with regard to e.g. light levels or cardinal direction. In leaning trees, HW formation was highly irregular, and again the distance from the stem pith to the HW boundary differed significantly around the stem $\left(F_{3,67}=22.4, P<0.001\right)$ with the longest axis in the side of the tree above the direction of lean. The number of annual rings transformed into HW followed the same pattern, with significantly more rings transformed into HW above the direction of stem lean compared to both perpendicular and below the direction of lean $\left(F_{3,46}=8.33, P<0.001\right)$. The mean proportion of HW was therefore significantly greater in the side of the tree above the direction of lean, compared to both perpendicular and below the direction of lean $\left(F_{2,263}=28.9\right.$, $P<0.001$, Fig. 5). When the proportion of HW between straight and leaning trees were compared, no significant differences were found, even when social status was taken into account.

\section{DISCUSSION}

Stem CSA was a good predictor of HW CSA and significantly more HW per unit area of stem was produced in dominant trees. Similar results were also found by Ferguston (1934) and Okuyama et al. (2000) studying teak in Indonesia, although tree social status was not taken into account in these studies. Bhat (1995) and Kjaer et al. (1999) found that HW proportion was correlated to DBH and growth ring width. Meinzer et al. (2001) studied 27 co-occurring tree species in a Panamanian forest also found that in all species SW area was highly dependent on stem diameter and was strongly linked to sap flow dynamics. Such data support the theory that allometric scaling of plant vascular systems is universal (Reich et al., 1997). In our study, dominant trees had the smallest proportion of SW, because they were significantly taller with thicker stems than trees from other social classes but SW width and stem taper were similar for all trees. Suppressed trees had the smallest area of SW because larger trees must produce more $\mathrm{SW}$ volume in order to sustain a similar growth rate in stem diameter over time, as this volume is distributed over a larger surface (Morataya et al., 1999). In dominant teaks, the height of the crown was at $70 \%$ of total tree height, compared to only $61 \%$ and $62 \%$ in suppressed and co-dominant trees. After crown closure, crown recession occurs (Morataya et al., 1999), resulting in trees with higher crowns. In very dense stands, lateral crown expansion will be hindered. Therefore, to maintain $\mathrm{SW}$ at an optimal size for conduction, HW proportion will increase, especially in trees where crowns are receding. Foliage biomass in the crown must nevertheless increase over time in order to sustain rapid stem diameter growth, illustrating the importance of timely density reductions in stands (Morataya et al., 1999).

Our results showed that teak growth ring width was positively correlated precipitation for the months of March and May for the current year and May of the preceding year. These months correspond to the onset of the rainy season. Pumijumnong et al. (1995) and Brienen and Zuidema (2005) showed that in teak in Northern Thailand and certain rainforest species in Bolivia, respectively, there is a greater sensitivity to rainfall at the beginning of the rainy season. During the dry season the cambial zone of teak is dormant (Rao and Rajput, 1999). Therefore it seems probable that the positive correlation with growth at the beginning of the rainy season occurs during bud-break (occurring at end of March to beginning of April in Tchorogo), although Rao and Rajput (1999) noted a lag of 4 weeks between bud-break and an increase in radial cambial activity in teak from western India. In the weeks after the first rainfall of the season, fine root growth will increase rapidly, reflected in the positive increase in radial growth seen in March. The negative correlations observed for the month of February in the current year correspond to the period just before bud-break. Heavy rainfall events can occur at Tchorogo during February, when the cambium is usually dormant. Trees are sensitive to water supply from roots during this period (Rojas-Jiménez et al., 2007) and if root growth is stimulated through sporadic precipitation, the consequences for stem radial growth may be negative, as the soil dries again and roots die back. Likewise in October, radial growth ceases quickly with the onset of the dry season, but sporadic rainfall events may perturb cambial functioning.

Unlike Shah et al. (2007), who found that the effect of precipitation on Himalayan teak radial growth was greater than that of temperature, we found that temperature had a much greater effect than precipitation. Ring width was positively correlated with mean monthly temperature for February, April-October of the preceding year and for February, AprilAugust, and October for the current year. The most significant correlation and response function coefficients were for 
the months of July in the preceding year and June and July in the current year, therefore suggesting that a temperature of $27-30{ }^{\circ} \mathrm{C}$ is optimal for teak radial growth in Togo. This value is lower than that found by Rao and Rajput (1999) who demonstrated that a temperature of $34-36{ }^{\circ} \mathrm{C}$ in western India was optimal for cambial activity in teak, but in Togo, temperatures do not reach such high values. We also found a negative correlation for January of the current year, falling well within the dry season and when temperatures are at their lowest. During this month, the cold, dry Harmattan wind blows across Togo and minimum temperatures can reach $18-20{ }^{\circ} \mathrm{C}$, much lower than that required for optimal cambial functioning in teak. Temperature is considered as one of the most important factors driving meristematic growth processes (Fourcaud et al., 2008). Therefore, cambial growth is probably triggered by a rise in temperature in March and growth processes can draw on reserves from the previous year. In our study, trees from all social classes responded in the same way to monthly variations in climate, therefore different responses to precipitation and temperature could not be detected at the level of individual trees in plantation teak.

The age of 8-9 y for the potential breakpoint between JW and AW was low, considering that Bhat et al. (2001) found a breakpoint between 15 and $25 \mathrm{y}$, depending on the criteria used. However, we used radial growth only as a criterion for JW formation and the maximal age of trees we studied was $24 \mathrm{y}$. It is likely that this breakpoint corresponds to the inflection point, defined as the point where growth increment culminates and the initial period of accelerated growth shifts to the period of deceleration, and found to be between 6 and $8 \mathrm{y}$ in teak from Kerala, India (Rugmini and Jayaraman, 2009). Unlike Priya and Bhat (1998) who found that false rings were frequent in JW of Indian teak, we found distinct growth rings in JW and an absence of false rings. To determine the age at which AW forms in Togolese teak, it would be necessary to carry out more studies using different characters e.g. wood anatomy and mechanical properties on older trees (Bhat et al., 2001; Kokutse et al., 2004).

The proportion of SW transformed into HW was significantly augmented along given axes in leaning trees, as suggested by Stokes and Berthier (2000) and Berthier et al. (2001) studying the temperate conifer Pinus pinaster Ait. However, unlike $P$. pinaster, where HW formation increased on the compressed side of leaning trees, in teak more growth rings were transformed into $\mathrm{HW}$ on the side of the tree held in tension i.e. above the lean. The actual mechanism governing this formation of eccentric HW formation is not yet known, but Berthier et al. (2001) suggested that mechanical loading through dynamic wind stress or stem lean may induce $\mathrm{HW}$ formation in conifer wood held under compression. As eccentric HW formation in conifers is also related to the presence of compression wood (Stokes and Berthier, 2000), a mechanical stimulus seems likely in inducing HW. In broadleaf species such as teak, tension wood forms on the upper sides of leaning trees (Timell, 1986). We did not observe if tension wood was present in the teak trees examined in this study, but it seems possible that a similar mechanism causing reaction wood formation also influences HW development. Although eccentric
HW formation was also observed in straight trees, it was not clear what the cause was. Either some stem lean had occurred in the past which was not evident when we measured the trees, or asymmetric crown development had resulted in an unequal distribution of stem weight, causing a build-up of mechanical stresses inside the tree. Such stresses could also possibly influence HW formation, in the same way that they affect reaction wood development (Fourcaud et al., 2003). Further studies should be carried out to determine if the eccentric HW development on the tension side of leaning trees occurs in broadleaf species in general.

Although the mechanism causing eccentric HW formation is not known, Berthier et al. (2001) showed that asymmetric HW development around the stem results in an optimal and constant surface area of SW. In regions where water supply is limited periodically, it is less costly to maintain a low volume of SW. In leaning trees, eccentric radial growth occurs to strengthen zones which are likely to failure due to self weight or dynamic loading (Hillis, 1987). This eccentric radial growth results in larger growth rings which would thus result in a thicker SW in that region of the tree. If asymmetric HW formation did not occur, SW surface area would be much greater and more costly to maintain. Few studies exist on eccentric HW formation in different tree species (Hillis, 1987), and it would be of great interest to determine the influence of climate factors on its occurrence.

The analysis of growth ring width from 1981 to 2004 showed that stand density was very high and little release in radial growth occurred after thinning. The current stand density of 1000-1200 stems ha ${ }^{-1}$ is thus too high and should be reduced to 300-500 stems ha ${ }^{-1}$ (Dupuy et al., 1999). In particular, thinning of suppressed trees, which make up $80 \%$ of the plantation, seemed to have little effect on growth. Nevertheless, if stand density was reduced, and tree size increased, stem diameter would probably increase, as also demonstrated by Pérez and Kanninen (2005).

In conclusion, our results showed that radial growth depends mainly on temperature, with a peak in growth occurring when temperatures reach $27-30{ }^{\circ} \mathrm{C}$ and that responses are similar regardless of tree social status. The proportion of HW formation was similar in leaning and straight trees but was significantly greater on the upper side of leaning trees. HW area per unit area of the stem was greatest in dominant trees, but in order to maintain rapid stem growth, stand density should be reduced to encourage crown expansion.

Acknowledgements: Funding was provided by the International Foundation for Science (IFS), Sweden. Thanks are due to F. Lagane and D. Bert (INRA Bordeaux) for help with growth ring analysis. Technical support and meteorological data were provided by ODEF (Office de Développement et d'Exploitation des Forêts), Togo. AMAP (Botany and Computational Plant Architecture) is a joint research unit which associates CIRAD (UMR51), CNRS (UMR5120), INRA (UMR931), IRD (2M123), and Montpellier 2 University (UM27). 


\section{REFERENCES}

Alteyrac J., Cloutier A., and Zhang S.Y., 2006. Characterization of juvenile wood to mature wood transition age in black spruce (Picea mariana (Mill) B.S.P.) at different stand densities and sampling heights. Wood Sci. Technol. 40: 124-138.

Aubréville A., 1937. Les forêts du Dahomey et du Togo, Bulletin du Comité d'études historiques 29: 1-113.

Behaghel I., 1999. État des plantations de teck (Tectona grandis L.f.) dans le monde. Bois For. Trop. 269: 5-18.

Bert D. and Danjon F., 2006. Carbon concentration variations in the roots, stem and crown of mature Pinus pinaster (Ait.). For. Ecol. Manage. 222: 279-295.

Berthier S., Kokutse A.D., Stokes A., and Fourcaud T., 2001. Irregular heartwood formation in Maritime Pine (Pinus pinaster Ait): consequences for biomechanical and hydraulic tree functioning. Ann. Bot. 87: $19-25$.

Bhat K.M., 1995. A note on heartwood proportion and wood density of 8-year-old teak. Indian For. 121: 514-517.

Bhat K.M., Priya P.B., and Rugmini P., 2001. Characterisation of juvenile wood in teak, Wood Sci. Tech. 34: 517-532.

Bhat K.M. and Florence E.J.M., 2003. Natural decay resistance of juvenile teak wood grown in high input plantations. Holzforschung 57: $53-55$.

Biondi F. and Waikul K., 2004. DENDROCLIM2002: a $\mathrm{C}^{++}$program for statistical calibration of climate signals in tree-ring chronologies. Comp. Geo. 30: 303-311.

Brienen R.J.W. and Zuidema P.A., 2005. Relating tree growth to rainfall in Bolivian rain forest: a test for six species using tree ring analysis. Oecologia 146: 1-12.

Devall M.S. and Parresol B.R., 2005. A dendrochronological study of teak (Tectona grandis L.f., Verbenaceae) in Puerto Rico. In: Bhat K.M., Nair K.K.N., Bhat K.V., Muralidharan E.M., and Sharma J.K. (Eds.), International Conference of Quality Timber products of Teak from Sustainable Forest Management, Kerala Forest Research Institute, Peechi, India, pp. 499-505.

Dupuy B., Maître H.F., and Kanga N.A., 1999. Table de production du teck (Tectona grandis L. f.). L'exemple de la Côte d'Ivoire. Bois For. Trop. 261: 8-16.

Eckstein D., Krause C., and Bauch J., 1989. Dendroecological investigation of spruce trees (Picea abies (L.) Karst.) of different damage and canopy classes. Holzforschung 43: 411-417.

Ern H., 1979. Die Vegetation Togos, Gliederrung, Gefährdung, Erhaltung. Willdenowia 9: 295-312.

FAO, 2001. Évaluation des ressources forestières mondiales 2000, Études FAO Forêts, $\mathrm{N}^{\circ} 140$. FAO, Rome, Italie.

Ferguston J.H.A., 1934. De Dikte van Kern en spinthout van den djati (Tectona grandis L.f.) (Thickness of heartwood and sapwood of teak). Mededeelingen van het Boschbouwproefstation 43: 1-19.

Fourcaud T., Blaise F., Lac P., Castéra P., and De Reffye P., 2003. Numerical modelling of shape regulation and growth stresses in trees, II-Implementation in the AMAPpara software and simulation of tree growth. Trees 17: 31-39.

Fourcaud T., Zhang X., Stokes A., Lambers H., and Körner C. 2008. Plant growth modelling and applications: the increasing importance of plant architecture in growth models. Ann. Bot. 101: 1053-1063.

Fritts H.C., 1976. Tree rings and climate, Academic Press, London, 567 p.

Haupt M., Leithoff D., Meier D., Puls J., Richter H.G., and Faix O., 2003. Heartwood extractives and natural durability of plantationgrown teakwood (Tectona grandis L.) - a case study. Holz. Roh. Werkst. 61: 473-474.

Hillis W.E., 1987. Heartwood and tree exudates, Springer Verlag, Berlin.
Kjaer E.D., Kajornsrichon S., and Lauridsen E.B., 1999. Heartwood, calcium and silica content in five provenances of teak (Tectona grandis). Silvae Genet. 48: 1-3.

Kokou K., 1998. Les mosaïques forestières au Sud du Togo: biodiversité, dynamique et activités humaines. Ph.D. thesis, Montpellier 2 University, France.

Kokutse A.D., 2002. Analyse de la qualité du bois de teck (Tectona grandis L.f.) en plantation au Togo: formation du bois de cœur, propriétés mécaniques et durabilité. Ph.D. thesis, Bordeaux I University, No. 2394, France.

Kokutse A.D., Baillères H., Stokes A., and Kokou K., 2004. Proportion and quality of heartwood in Togolese teak (Tectona grandis L.f.). For. Ecol. Manage. 189: 37-48.

Kokutse A.D., Stokes A., Baillères H., Kokou K., and Baudassé C., 2006. Decay resistance of Togolese teak (Tectona grandis L.f.) heartwood and relationship with colour. Trees 20: 219-223.

Longuetaud F., Mothe F., Leban J.M., and Mäkelä A., 2006. Picea abies sapwood width: variations within and between trees. Scand. J. For. Res. 21: 41-53.

Medzegue M., Grelier S., M'Batchi B., Nziengui M., and Stokes A., 2007. Radial growth and characterization of juvenile and adult wood in plantation grown Okoumé (Aucoumea klaineana Pierre) from Gabon. Ann. For. Sci 64: 815-824.

Meinzer F.C., Goldstein G., and Andrade J.L., 2001. Regulation of water flux through tropical forest canopy trees: do universal rules apply? Tree Physiol 21: 19-26.

Morataya R., Galloway G., Berninger F., and Kanninen M., 1999. Foliage biomass - sapwood (area and volume) relationships of Tectona grandis L.f. and Gmelina arborea Roxb.: silvicultural implications. For Ecol. Manage. 113: 231-239.

Murphy J.O., 1994. A dendroclimatic study of teak from East Java, Proceedings of the Koninklijke Nederlandse Akademie van Wetenschappen. Biol. Chem. Geol. Phys. Medic. Sci. 97: 183-199.

Okuyama T., Yamamoto H., Wahyudi I., Hadi Y.S., and Bhat K.M., 2000. Growth stresses and some wood quality attributed in planted teak. In: Proceedings of the IUFRO Congress, Kuala Lumpur, Malaysia.

Oosterbaan R.J., 2005. SegReg., Segmented Linear Regression, http:// www.waterlog.info.

Pardé J. and Bouchon J., 1988. Dendrométrie, ENGREF, Nancy.

Pérez C. and Kanninen M., 2005. Effect of thinning on stem form and wood characteristics of teak (Tectona grandis) in a humid tropical site in Costa Rica. Silva. Fenn. 39: 217-225.

Piutti E. and Cescatti A., 1997. A quantitative analysis of the interactions between climatic respons and intraspecific competition in European beech. Can. J. For. Res. 27: 277-284.

Plauborg K.U., 2004. Analysis of radial growth responses to changes in stand density for four tree species. For. Ecol. Manage. 188: 65-75.

Priya P.B. and Bhat K.M., 1998. False ring formation in teak (Tectona grandis L.f.) and the influence of environmental factors. For. Ecol. Manage. 108: 215-222.

Pumijumnong N., Eckstein D., and Sass U., 1995. Tree-ring research on Tectona grandis in northern Thailand. IAWA J. 16: 385-392.

Rao K.S. and Rajput K.S., 1999. Seasonal behaviour of vascular cambium in teak (Tectona grandis) growing in moist deciduous and dry deciduous forests. IAWA J. 20: 85-93.

Reich P.B., Walters M.B., and Ellsworth D.S., 1997. From tropics to tundra: Global convergence in plant functioning. Proc. Natl. Acad. Sci. USA 94: 13730-13734.

Rojas-Jiménez K., Holbrook N.M., and Gutiérrez-Soto M.V., 2007. Dry-season leaf flushing of Enterolobium cyclocarpum (ear-pod tree): above- and belowground phenology and water relations. Tree Physiol. 27: 1561-1568.

Rugmini P. and Jayaraman K., 2009. Intrinsic units of growth for teak trees. Trees 23: 51-58. 
Sahri M.H., Boupha L., Nobuchi T., and Jusoh M.Z., 1998. Wood quality assessment of plantation grown Azadirachta excelsa from Malaysia. IAWA J. 19: 476.

Sellin A., 1996. Sapwood amount in Picea abies (L) karst determined by tree age and radial growth rate. Holzforschung 50: 291-296.

Shah S.K., Bhattacharyya A., and Chaudhary V., 2007. Reconstruction of June-September precipitation based on tree-ring data of teak (Tectona grandis L.) from Hoshangabad, Madhya Pradesh, India. Dendrochronologia 25: 57-64.

Stokes A. and Berthier S., 2000. Irregular heartwood formation in Pinus pinaster Ait. is related to eccentric, radial, stem growth. For. Ecol. Manage. 135: 115-121.

Stokes M.A. and Smiley T.L., 1968. An introduction to tree-ring dating, University of Chicago Press, Chicago.
Timell T.E., 1986. Compression wood in Gymnosperms, Springer Series in Wood Science, Berlin.

Trouet V., Coppin P., and Beeckman H., 2006. Annual growth ring patterns in Brachystegia spiciformis reveal influence of precipitation on tree growth. Biotropica 38: 375-382.

Van Deusen P.C., 1990. A dynamic program for cross-dating tree rings. Can. J. For. Res. 20: 200-205.

Wadsworth F.H., González E.G., Figueroa Colón, and J.C. Pérez J.L., 2003. Fifty-nine-year performance of planted big-leaf mahogany (Swietenia macrophylla King) in Puerto Rico. In: Big-Leaf Mahogany, Genetics, Ecology, and Management, Ecological Studies, Vol. 159, Springer, pp. 342-357.

Zobel J.B. and van Buijtenen J.P., 1989. Wood variation. Its causes and control, Springer, Series in Wood Science, Berlin. 